\title{
A search for new group-B streptococcal serotypes
}

\author{
JITKA MOTLOVÁ, M. WAGNER* AND JARMILA JELÍNKOVÁ \\ Department of Medical Microbiology, Postgraduate Medical Institute and the Streptococcus \\ Reference Laboratory, 10042 Prague 10, Šrobárova 48, Czechoslovakia; and * Central Institute \\ of Microbiology and Experimental Therapy, 6900 Jena, Beutenbergstrasse 11, German \\ Democratic Republic
}

\begin{abstract}
Summary. New serotypes were sought among 165 clinical isolates of group-B streptococci that were untypable by antisera for the conventional types Ia, Ib, II and III. The strains were tested for sialic acid, an integral component of the group-B streptococcal type-polysaccharides; trypsin-treated bacteria were tested by slideagglutination with the sialic-acid-specific lectin from the snail Cepaea hortensis. Sialic acid was detected in 96 of the strains; in 95 of these, new type antigens were identified serologically (type IV, 52; provisional type V, 34; candidate type NT6, seven; provisional type V and candidate type NT6, one; candidate type 7271 , one); the remaining strain was found to possess a small amount of Ia antigen. Sialic acid was not detected in 69 strains, and none of these possessed a polysaccharide type-antigen. Chemical measurement of the sialic-acid content of cultures by Aminoff's method gave results in conformity with the lectin-agglutination test and the presence of polysaccharide type-antigens.
\end{abstract}

\section{Introduction}

The identification of serotypes among group-B streptococci (GBS) is of both clinical and epidemiological importance (Christensen et al., 1985), but not all strains fall into the four polysaccharide types defined by Lancefield $(1934,1938)$; over $10 \%$ of those isolated from human sources are untypable (NT). It is therefore desirable to extend the typing system by the establishment of new types.

In the native form, the conventional type-specific polysaccharides Ia, Ib, II and III all contain sialic acid, the N-acetyl-neuraminic acid (Jennings et al., $1980,1983 a$ and $b$ ) which has not been detected in the group-specific polysaccharide of GBS (Swenson et al., 1982). Recently, Wagner (1982) and Wagner et al. (1982) in Jena found that the sialic-acidspecific lectin from the snail Cepaea hortensis agglutinated all their type Ia, Ib, II and III strains and some NT GBS strains but did not agglutinate streptococci of other serological groups. At the same time, the Prague Streptococcus Reference Laboratory (Jelínková, 1982; Jelínková and Motlová, 1985a) was studying the candidates for new GBS types proposed by various laboratories. All strains of the new serotype IV were found to give

Received 8 Jul. 1985; revised version accepted 14 Nov. 1985. positive results in the $C$. hortensis lectin-agglutination test.

Collaborative work in Prague and Jena, in which lectin prepared in Jena was used in standardised procedure, fully confirmed the findings of Wagner (1982). Moreover, the lectin agglutinability of some NT strains suggested the presence in them of new type polysaccharides, which were later defined by the production of precipitating antisera (Jelinková and Motlová, 1985b). Thus, the detection of sialic acid by means of the $C$. hortensis lectin could be used to narrow the field in the search for new polysaccharide types. In our account of these studies we use the nomenclature of GBS types proposed by Jelínková (1982) and Henrichsen et al. (1984).

\section{Materials and methods}

\section{Reference strains}

The numbers of the strains employed were as follows: group B, no. 090R var; type Ia, no. 090R; type Ib, no. H36B; type Ia/c (originally named type Ic), no. A909; type II, no. 18RS21: type III, nos. 6313 and D136C; type IV, no. 3139 (see Rabinowitz et al., 1980); protein R, no. NCTC 9828; protein X, no. NCTC 9829; provisional type 
V (Jelinková and Motlová, 1985b). no. 1169 (described by Wilkinson, 1977 as "NTl"); type candidate NT6 (Wilkinson. 1977), no. 1214; type candidate 7271 (Perch et al., 1979), no. 7271.

\section{Untypable isolates of $G B S$}

Our collection of 165 strains that were untypable by means of antisera Ia, Ib, II and III had been selected from 1708 isolates of GBS of human origin received from various locations in the years $1964-84 ; 75$ of them carried one or more of the protein antigens $c$ (formerly named Ibc). $\mathrm{R}$ and $\mathrm{X}$.

\section{Typing method}

Antisera were prepared in rabbits by the intravenous injection of heat-killed suspensions of streptococci (Jelinkova. 1977). The conventional set of diagnostic typing sera la, Ib. II and III supplemented with sera against protein antigens c, $R$ and $X$ (set 1) was extended in 1982 by adding sera against type IV, provisional type $V$ and the type candidates NT6 and 7271 (set 2). Streptococci were extracted with $0.2 \mathrm{M} \mathrm{HCl}$ at $52 \mathrm{C}$ for $2 \mathrm{~h}$ and the extracts neutralised with $1.0 \mathrm{M} \mathrm{NaOH}$. Ring-precipitation tests were performed in capillary tubes with a conical upper end. as described by Williams (1958).

\section{Lectin from Cepaea hortensis}

This was isolated and partially purified as described earlier (Wagner. 1982). Briefly, powdered freeze-dried albumen glands of $C$. hortensis snails $(1 \mathrm{~g})$ were extracted twice with saline $(10 \mathrm{ml})$ at $4 \mathrm{C}$ overnight. After centrifugation the combined supernates were absorbed with packed group-C streptococcal cells of strain H46A at $37 \mathrm{C}$ for $1 \mathrm{~h}$ and then at $4 \mathrm{C}$ overnight to remove another lectin with a different specificity. They were then run down a Sephadex G100 column and the lectin-containing fractions were pooled. dialysed against distilled water and freeze-dried.

\section{Bacterial suspensions for the lectin-agglutination test}

These were deposited by centrifuging $5 \mathrm{ml}$ of a $17-\mathrm{h}$ culture grown in Todd-Hewitt broth at $37 \mathrm{C}$. The sediment was washed three times with saline and treated with a $5 \%$ trypsin solution for $2 \mathrm{~h}$. Homogeneous suspensions of streptococci were mixed on a slide with a solution of lectin in saline, $5 \% \mathrm{w} / \mathrm{v}$. Strong agglutination within 1 min was considered a positive reaction $(+)$ and a weak, incomplete agglutination an equivocal reaction $( \pm)$

\section{Quantitatice determination of sialic acid}

Streptococci grown in Todd-Hewitt broth enriched with glucose and $\mathrm{Na}_{2} \mathrm{HPO}_{4}$ (Baker and Kasper, 1976a and $b$ ) were deposited by centrifugation, washed twice with distilled water and freeze-dried. Hydrochloric acid extracts of the bacteria were prepared by heating $25 \mathrm{mg}$ of freeze-dried cells suspended in $1.25 \mathrm{ml}$ of $0.1 \mathrm{M} \mathrm{HCl}$ at $84 \mathrm{C}$ in a water-bath for $20 \mathrm{~min}$. The precipitated protein was removed by centrifugation $(3000 \mathrm{rpm}, 20 \mathrm{~min})$ and the sialic-acid content of the supernate was analysed by the thiobarbituric-acid method (Aminoff, 1961); $\mathrm{N}$-acetyl-neuraminic acid was used as the standard.

\section{Results}

The 165 untypable strains of GBS were subjected to the $C$. hortensis lectin-agglutination test, and 96 $(58 \%)$ of them gave a positive reaction (table I), indicating the presence of sialic acid and hence the potential presence of a new type polysaccharide. All but one of these strains gave precipitation reactions with sera against new polysaccharide types included in set 2 . The number of strains in which each of the new polysaccharide antigens was detected were type IV, 52; provisional type V, 34; candidate type NT6, seven, and candidate type 7271 , one; and one strain reacted with antisera for both provisional type $V$ and candidate type NT6. The remaining strain that gave a positive lectin-agglutination test (no. 693) did not give a precipitation reaction with any of the sera in set 2, but when the test was repeated with an extract of twice the volume of cells used in the routine precipitation test, a weak but definite reaction with type Ia serum was obtained.

Table I. Agglutination of untypable* group-B streptococci by a sialic-acid-specific lectin as an indicator of the presence of new type polysaccharides

\begin{tabular}{|c|c|c|}
\hline \multirow[b]{2}{*}{$\begin{array}{l}\text { New type } \\
\text { polysaccharide }\end{array}$} & \multicolumn{2}{|c|}{ Lectin-agglutination test } \\
\hline & $\begin{array}{l}\text { negative } \\
(n=69)\end{array}$ & $\begin{array}{l}\text { positive } \\
(n=96)\end{array}$ \\
\hline Type IV & 0 & 52 \\
\hline PT V & 0 & $35 t$ \\
\hline CT NT6 & 0 & $8+$ \\
\hline CT 727I & 0 & 1 \\
\hline Any of the above & 0 & 95 \\
\hline None of the above & 69 & $1+$ \\
\hline \multicolumn{3}{|c|}{$\begin{array}{l}\text { PT = provisional type; CT = candidate type. } \\
\text { Conventional type polysaccharides Ia, Ib, II and } \\
\text { III not detected. } \\
\text { † One strain reacted with sera for PT V and CT NT6. } \\
+ \text { In subsequent tests one strain gave a weak reaction } \\
\text { with serum for type Ia. }\end{array}$} \\
\hline
\end{tabular}


Table II. Quantitative detection of sialic acid in selected GBS strains of group-B streptococci that gave doubtful results in the lectin-agglutination and serotyping tests

\begin{tabular}{cc|ccc}
\hline & $\begin{array}{c}\text { Strain } \\
\text { no. }\end{array}$ & $\begin{array}{c}\text { Lectin- } \\
\text { agglutination } \\
\text { test }\end{array}$ & $\begin{array}{c}\text { Typing results with } \\
\text { sera of set 2 }\end{array}$ & $\begin{array}{c}\text { Sialic acid, } \\
\mu \mathrm{g} / 10 \mathrm{mg} \\
\text { dry weight of cells }\end{array}$ \\
\hline Doubtful results & 693 & + & Ia weak & 42 \\
& 100 & - & Ib trace & $<2$ \\
& 335 & - & III trace & $<2$ \\
& 792 & - & V trace & $<2$ \\
& 559 & \pm & NT/c & $<2$ \\
& 191 & \pm & NT & $<2$ \\
& 630 & \pm & NT & $<2$ \\
& 960 & \pm & III trace & $<2$ \\
& 597 & \pm & III trace & $15 \cdot 5$ \\
& 407 & \pm & V trace & $10 \cdot 5$ \\
& 068 & - & NT/c & $<2$ \\
& 277 & - & NT/c & $<2$ \\
& 192 & - & NT & $<2$ \\
& 337 & - & NT & $<2$ \\
& 168 & + & IV/c & $48 \cdot 3$ \\
& 905 & + & V & $23 \cdot 7$ \\
\hline
\end{tabular}

Table III. Distribution of new type polysaccharides and of protein antigens among untypable* group B streptococci

\begin{tabular}{lcccc}
\hline & \multicolumn{2}{c}{$\begin{array}{c}\text { Number of strains with the indicated type } \\
\text { polysaccharide and }\end{array}$} \\
\cline { 2 - 5 } \multicolumn{1}{c}{$\begin{array}{c}\text { New type } \\
\text { polysaccharide }\end{array}$} & $\begin{array}{c}\text { no protein } \\
\text { antigen }\end{array}$ & $\mathrm{c}$ & $\mathrm{R}$ & $\mathrm{X}$ \\
\hline Type IV & 30 & 17 & 3 & 2 \\
PT V & $25 \dagger$ & 5 & 3 & 3 \\
CT NT6 & $4 \dagger$ & 3 & 0 & 1 \\
CT 7271 & 1 & 0 & 0 & 0 \\
None & $31 \ddagger$ & 27 & 9 & 3 \\
\hline
\end{tabular}

For abbreviations, and footnotes $*, \dagger, \ddagger$, see table I.

None of the 69 strains that failed to give a positive lectin-agglutination test (table I) gave a definite precipitation reaction with anti-polysaccharide sera in set 2 , though a few of them gave trace reactions (see below).

In all, 10 of the 165 strains gave doubtful or discrepant results in the two tests for sialic-acidcontaining polysaccharides (table II). In addition to no. 693 , these included strains that gave an equivocal reaction in the lectin-agglutination test, a trace reaction in the precipitation test, or both. These strains were subjected to a quantitative assay of their sialic acid and to repeated serotyping with double-strength extracts. Strain 693 possessed a high content of sialic acid $(42 \mu \mathrm{g} / 10 \mathrm{mg}$ dry weight of cells) in agreement with the detection of Ia polysaccharide by the modified technique. Of the nine remaining strains, none of which gave definite evidence of a polysaccharide antigen on repeated serotyping, seven yielded less than detectable amounts of sialic acid $(<2 \mu \mathrm{g} / 10 \mathrm{mg}$ dry weight of cells); two had an intermediate content of sialic acid (15.5 and $10.5 \mu \mathrm{g} / 10 \mathrm{mg}$ dry weight of cells) which might indicate the possible presence of an undetected type polysaccharide.

Table III shows the distribution among the initially untypable strains of new polysaccharides and of the protein antigens $c, R$ and $X$. 


\section{Discussion}

The serological demonstration of new type polysaccharides in lectin-agglutinable NT strains is evidence that sialic acid is a component of the type antigens of type IV, provisional type $\mathrm{V}$ and candidate type NT6, and most likely also of candidate type 7271 . The affinity of the sialic-acid-specific lectin from $C$. hortensis for both the polysaccharide antigens of the Lancefield-defined types and the newly investigated type polysaccharides suggest that they have a corresponding chemical structure.

So far, there is no information about the chemical makeup of the new types and type candidates. The proportions of the individual components in the conventional type-polysaccharides are known. Sialic acid, an acid-labile component, is invariably present in the native (structurally and immunologically complete) forms of these antigens (Jennings et al. . 1980, 1983a and b). Our method of mild $\mathrm{HCl}$ extraction of the antigen from selected GBS strains gave quantitative values for sialic-acid content that were in conformity with the results of the lectin slide-agglutination test and in correspondence with the serotyping results. We are at present studying the sialic-acid content of the reference strains for conventional, new, and candidate serotypes by the same method.

Among our 165 NT GBS strains selected from a large collection of NT strains assembled during some 20 years we failed to find any further prospec-

\section{REFERENCES}

Aminoff D 1961 Methods for the quantitative estimation of $N$ acetylneuraminic acid and their application to hydrolysates of sialomucoids. Biochemical Journal 81:384-392.

Baker C J, Kasper D L $1976 a$ Microcapsule of type III strains of group B streptococcus: production and morphology. Infection and Immunity 13:189-194

Baker C J, Kasper D L 1976 b Identification of sialic acid in polysaccharide antigens of group B streptococcus. Infection and Immunity 13:284-288.

Baker C J, Kasper D L, Davis C E, 1976 Immunochemical characterization of the "native" type III polysaccharide of group B streptococcus. Journal of Experimental Medicine 143:258-270.

Bergner-Rabinowitz S, Ferne M, Halfon S T 1980 Group B streptococci: different serotypes associated with clinical infections. Laboratory Practice 29:733-734.

Christensen K K. Christensen P, Ferrieri P (eds) 1985 Neonatal group B streptococcal infections (Antibiotics and Chemotherapy, vol. 35) Karger, Basel.

Doran T I, Straus D C, Mattingly S J 1980 Extracellular antigens of serotype III group B streptococci. Infection and Immunity 30:890.893.

Henrichsen J. Ferrieri P, Jelinková J, Köhler W, Maxted W R 1984 Nomenclature of antigens of group B streptococci. International Journal of Systematic Bacteriology 34:500. tive candidates for new polysaccharide types. All the initially untypable strains that were shown by the screening lectin-agglutination test to contain sialic acid also possessed one of the new polysaccharides. The possibility cannot be excluded that some of the lectin-negative GBS contain an amount of type-polysaccharide antigen undetectable by our methods; one must bear in mind the many factors that influence the synthesis and detectability of type antigens or their components (Wilkinson, 1975; Baker et al., 1976; Kane and Karakawa, 1977; Kasper et al., 1979; Tai et al., 1979; Doran et al., 1980).

In any event, the extended typing scheme substantially reduces the number of NT strains. The type candidates NT6 and 7271 have maintained their position in the present study, but in our opinion a continued search for new type-candidates is not economically justifiable at present.

Many of the GBS strains that are devoid of polysaccharide antigens can be defined in terms of the protein antigens $\mathrm{c}, \mathrm{R}$, and $\mathrm{X}$, and the possible existence of other protein antigens cannot be excluded. In all, about one-half of all strains possess one or more protein antigens, either alone or in combination with a type polysaccharide, and these are often valuable markers for strain differentiation.

The skilful technial assistance of Mrs B. Behnke and Mrs I. Otum is gratefully acknowledged.

Jelinková J 1977 Group B streptococci in the human population. Current Topics in Microbiology and Immunology 76:127165.

Jelinková J 1982 Frequency of serotypes in group B streptococcus isolates: new type candidate. In: Holm S E, Christensen $P$ (eds) Basic concepts of streptococci and streptococcal diseases. Reedbooks Ltd, Chertsey, pp 50-51.

Jelínková J, Motlová J $1985 a$ The nomenclature of group B streptococci. In: Christensen K K, Christensen P, Ferrieri P (eds) Neonatal group B streptococcal infections (Antibiotics and Chemotherapy, vol. 35) Karger, Basel, pp 49-52.

Jelinková J, Motlová $1985 b$ Worldwide distribution of two new serotypes of group B streptococci: type IV and provisional type V. Journal of Clinical Microbiology 21:361-362.

Jennings H J, Katsenellenbogen E, Lugowski C, Kasper D L $1983 a$ Structure of native polysaccharide antigens of type Ia and Ib group B streptococcus. Biochemistry 22:1258-1264.

Jennings H J, Rosell K G, Kasper D L 1980 Structural determination and serology of the native polysaccharide antigen of type III group B streptococcus. Canadian Journal of Biochemistry 58:112-120.

Jennings H J, Rosell K G, Katzenellenbogen E, Kasper D L $1983 \mathrm{~b}$ Structural determination of the capsular polysaccharide antigen of type II group B streptococcus. Journal of Biological Chemistry 258:1793-1798.

Kane J A, Karakawa W W 1977 Multiple polysaccharide antigens of group B streptococcus, type Ia: emphasis on a 
sialic acid type-specific polysaccharide. Journal of Immunology 118:2155-2160.

Kasper D L, Baker C J, Baltimore R S, Crabb J H, Schiffman G, Jennings H J 1979 Immunodeterminant specificity of human immunity to type III group B streptococcus. Journal of Experimental Medicine 149:327-339.

Lancefield R C 1934 A serological differentiation of specific types of bovine hemolytic streptococci (group B). Journal of Experimental Medicine 59:441-458.

Lancefield R C 1938 Two serological types of groups B hemolytic streptococci with related, but not identical, type-specific substances. Journal of Experimental Medicine 67:25-40.

Perch B, Kjems E, Henrichsen J 1979 New serotypes of group B streptococci isolated from human sources. Journal of Clinical Microbiology 10:109-110.

Swenson R M, DeCueninck B, Eisenstein T K, Greber T, Reasavy D, Shockman G D 1982 The soluble antigens of type III, II and Ia group-B streptococci. In: Holm S E, Christensen $\mathbf{P}$ (eds) Basic concepts of streptococci and streptococcal diseases. Reedbooks Ltd, Chertsey, pp 94-95.
Tai J Y, Gotschlich E C, Lancefield R C 1979 Isolation of typespecific polysaccharide antigen from group B type Ib streptococci. Journal of Experimental Medicine 149:58-66.

Wagner M 1982 Agglutination of bacteria by a sialic acidspecific lectin of the snail Cepaea hortensis. Acta Histochemica 71:35-39.

Wagner M, Wagner B, Günther E 1982 Interaction of a sialic acid-specific lectin of the snail Cepaea hortensis with group B streptococci. In: Holm S E, Christensen P (eds) Basic concepts of streptococci and streptococcal diseases. Reedbooks Ltd, Chertsey, pp 70-71.

Wilkinson H W 1975 Immunochemistry of purified polysaccharide type antigens of group B streptococcal types Ia, Ib, and Ic. Infection and Immunity 11:845-852.

Wilkinson H W 1977 Nontypable group B streptococci isolated from human sources. Journal of Clinical Microbiology 6:183-184.

Williams R E O 1958 Laboratory diagnosis of streptococcal infections. Bulletin of the World Health Organization 19:153-176. 